\title{
"Resta saber se o não-pensamento contamina o pensamento": citação e invenção em Adeus à Linguagem de Jean-Luc Godard
}

\author{
Helena Martins \\ Pontifícia Universidade Católica do Rio de Janeiro / CNPq
}

Resumo: Um dos traços reconhecidos do cinema de Jean-Luc Godard é sua singularidade no haver-se com o trabalho da citação. Celebra-se a força vertiginosa com que seus filmes deslocam, e fazem agir, os fragmentos "saídos de mil focos de cultura" de que falava Barthes, em suas tão citadas palavras sobre o reino inexorável da citação. Este artigo propõe uma reflexão pontual sobre os modos como essa espécie singular de (des)concerto verbivocovisual acontece em Adeus à Linguagem (2014). Respondendo à chamada deste volume, concentra-se na vida que levam no filme - e ao filme - alguns dos fragmentos literários ali convocados, com atenção especial às vozes de Valéry, Rilke, Beckett, Borges e Anouilh. "O face a face inventa a linguagem", ouvimos a certa altura, em meio ao vórtice de citações. Mostra-se aqui que o desejo de invenção e de alteridade manifesto nesse dito ganha agência nos modos como Godard põe face a face a literatura e o cinema - ao mesmo tempo que explora, entre outros, o face a face com o animal, a mulher, as margens do Ocidente, com a própria arte.

Palavras-chave: Jean-Luc Godard, Adeus à Linguagem, citação, invenção, alteridade

Abstract: One of the recognized traits of Jean-Luc Godard's cinema is its uniqueness in dealing with the work of quotation. Critics celebrate the dizzying forces with which his films displace and put into action fragments coming from "a thousand focuses of culture", to stay with Barthes's much-quoted words on inexorable sway of quotation. This article proposes a reflection on the ways this singular kind of verbivocovisual concert (or 
disconcert) takes place in the specific case of Goodbye to Language (2014). In answer to the proposal of this volume, it focuses on some of the literary fragments that are evoked there, examining the life they lead in and bring into the film. Special attention is given to the voices of Valéry, Rilke, Beckett, Borges, and Anouilh. "Being face to face invents language," we hear at one point, amidst the vortex of quotations. This article shows that the desire for invention and otherness manifested in this saying gets enacted in the ways Godard puts literature and cinema face to face - while exploring, at the same time, encounters involving animals, women, the margins of the West, and art itself.

Keywords: Jean-Luc Godard, Goodbye to language, quotation, invention, alterity

A certa altura do filme Adeus à Linguagem, de Jean-Luc Godard, vemos na tela, em primeiro plano, a silhueta escura de Roxy, o cachorro protagonista, de costas para nós, imóvel. A tela nos mostra também o que esse cachorro vê: um trem de alta velocidade passando rente à plataforma de uma estação. 0 trem passa em câmera lenta, em cadência ligeiramente descontínua, sincopada por mínimas pausas. Nesse caso, no entanto, a câmera lenta não funciona, como é comum, para franquear detalhes que se perderiam no registro sincrônico de um movimento veloz (como quando se ralenta, em filme, o cair de uma gota ou a trajetória de uma bala disparada). Ao contrário, o trem que vemos passar em câmera lenta se desfaz em rasgos horizontais de luz colorida, sinais de velocidade. 0 lento e o veloz se reúnem, assim, em uma espécie de oximoro visual - e é como se estivéssemos vendo passar, bem devagar, não o trem, mas a sua rapidez. A essa reunião improvável de ritmos e velocidades visuais, junta-se ainda, comovendo-nos pelos ouvidos, um trecho do segundo movimento da Sinfonia no. 7 de Beethoven.

A cena, que não dura mais de dez segundos, participa da vertigem paratática que marca o cinema de Godard: comparece em meio a uma sucessão de saltos, cortes abruptos de som e imagem, descontinuidades narrativas - é um dos tantos fragmentos verbivocovisuais que Godard vai derramando sobre os espectadores, com seu característico desapego pela costura e pela hierarquia. Nos segmentos imediatamente anterior e posterior a este, vemos o mesmo cão, mas longe da vida urbana, no campo. 


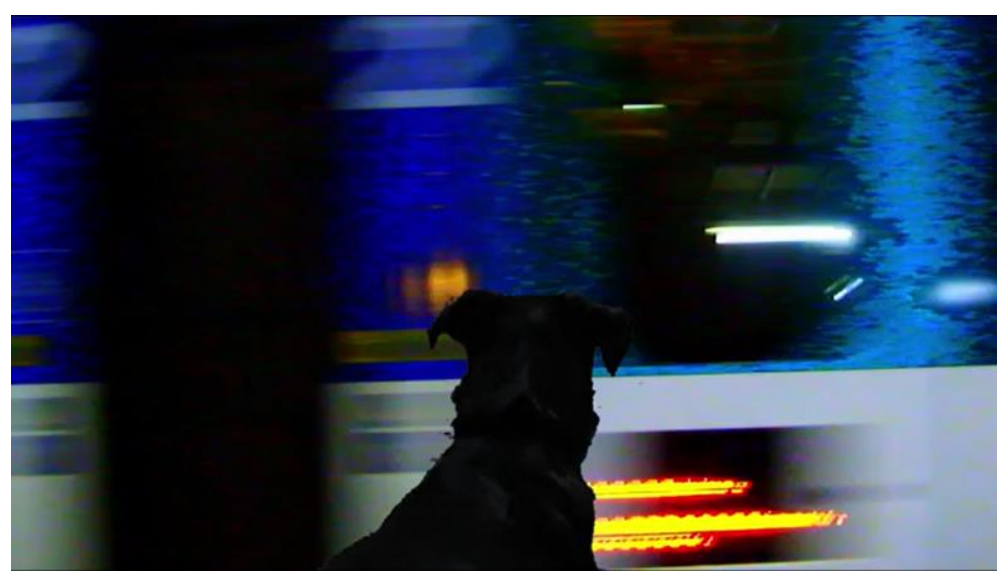

Fig. 1, Adeus à Linguagem, Roxy na estação de trem

Antes da cena da estação, ele vagueia por uma paisagem verde e húmida, segue por entre trilhas, poças, riachos, vai ao que parece ser um rio maior, com pedras, depois aparece à beira de um lago calmo, azul (o cartaz de Adeus à Linguagem). Como ocorre ao longo de todo o filme, essas imagens se movem diante de nossos olhos alternando-se entre o contínuo e o sincopado, entre a câmera lenta e a normal, entre o colorido - muitas vezes artificialmente estourado - e o preto e branco, ou quase. Também como em outros momentos do filme, pinturas ocupam subitamente a tela (com e sem a presença da mão de quem pinta); nesse caso, a tela se preenche inteira com uma abstração feita de pinceladas largas e espessas, em tons semelhantes aos da cena de natureza que teremos acabado de ver. A sinfonia de Beethoven, que retornará adiante, começa a soar para logo ser interrompida, como se num microdrama de criatura natimorta. As músicas do filme vivem um pouco mais ou um pouco menos, mas destinam-se quase sempre à ceifa abrupta experimentamos a comoção crescente que provocam e somos aturdidos por sua (quase injusta) interrupção, muito como nos cortes que atingem as imagens e as falas.

O que gostaria de destacar: numa sequência que se compreende entre dois flashes da mencionada pintura, o cachorro aparecerá de frente para a câmera, com o rio ao fundo, flagrado em sucessivas imagens fixas, as quais, um pouco como no ritmo de uma antiga projeção de slides, irão aproximando seus olhos cada vez mais da quarta parede - de nós. 


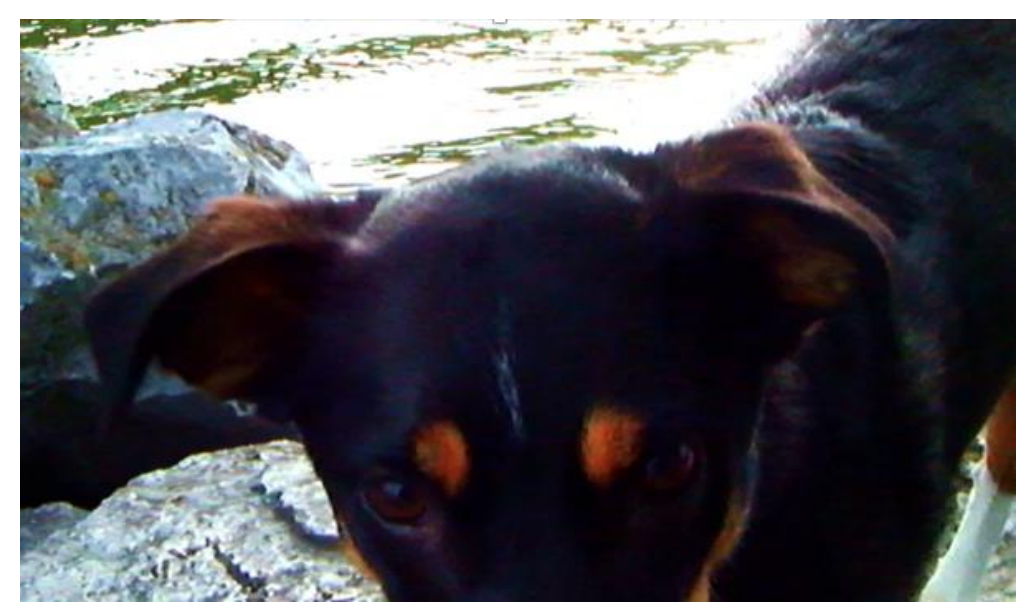

Fig. 2, Adeus à Linguagem, Roxy no campo

O cão nos olha de baixo para cima, diríamos que com uma espécie de "tenacidade silenciosa", expressão que ouvimos em outra parte do filme. Aqui, em voice-over, Godard diz algumas palavras que, conhecendo ou pesquisando, saberemos ser de autoria de Paul Valéry:

Nenhuma pessoa consegue pensar livremente quando seus olhos não se deixam apartar da companhia de outros olhos.

Desde que os olhares se prendem, com efeito, já não são mais dois, e surge a dificuldade de ficar sozinho. ${ }^{1}$

É com nossos olhos presos aos olhos do cachorro na tela que, com alguma sorte, teremos companhia e não conseguiremos pensar livremente. Antes de Godard terminar de dizer as palavras de Valéry, o cão já se terá desviado, indo entreter-se no lago azul. Mas teremos talvez sentido ou pressentido que os "olhares que se encontram fazem nascer estranhas relações": realizam um "quiasma de dois 'destinos', de dois pontos de vista"; instauram uma espécie de "limitação simultânea recíproca", na qual "o que me falta é esse mim mesmo [moi] que você vê" (Valéry 1960: 491). Você, o cão.

Mais uma tomada (tremulante) da pintura, e estamos de novo com a sinfonia de Beethoven: o cão agora está de perfil, na chuva, olhando a mata adiante, barulho de correnteza ao fundo. Transplanta-se então a sua figura, quase na mesma posição, para a 
estação de trem - como se apenas a paisagem e os barulhos de fundo (agora mecânicos), tivessem mudado. Quando, logo em seguida, a silhueta escura de Roxy aparecer de costas para nós, estaremos ainda, talvez, sob o efeito do quiasma de que fala Valéry - será um pouco como se aquela estranha percepção lenta da rapidez indiciasse algum contágio sensível entre nós e o cão, como se víssemos, contagiados pelo seu removido ponto de vista, a falta de nós mesmos que ele vê - algo que sabemos apenas não ser, por exemplo, o torvelinho insensato da nossa própria vida, frenética, passada em trens de alta velocidade.

Em novo corte abrupto, somos devolvidos ao campo, agora numa paisagem de inverno, nevada: acompanhamos os ademanes do cachorro se esfregando de costas na neve, depois sacudindo-se, para espanar o que se prendeu nos pelos e poder continuar a vaguear. Salta-se para um passeio da câmera pelas folhas amarelo-laranja de uma árvore contra um céu muito azul, cores estouradas, vivas, içando nos espectadores entusiasmos de infância, de novo com Beethoven. Corte de volta para o cão na neve, com voice-over de Godard, retomando Valéry: "surge a dificuldade de ficar sozinho". O cão então anda no campo na direção de uma estradinha asfaltada, aproximando-se da quarta parede, em câmera lenta, agora bastante sincopada por pausas. Ouvimos a voz de Godard dizer: "Não é o animal que é cego, mas o homem - cego pela consciência e incapaz de olhar o mundo".

A câmera então percorre o corpo do cachorro, subindo pelas patas até se fixar na cabeça, em imagem estática. Temos de novo diante de nós os olhos fixos do cão, enquanto Godard prossegue: "o que está fora, escreveu Rilke, só o sabemos pelo olhar do animal”2.

Essas palavras vêm da oitava das Elegias de Duíno, cujos primeiros versos, na tradução de Paulo Quintela (Rilke 1968: 69), dizem:

Com todos os olhos vê a criatura

o Aberto. Só os nossos olhos estão

como invertidos e de todo postos à volta dela

como armadilhas, em círculo à volta da sua saída livre.

O que está lá fora, só o sabemos da face

do animal; pois já a criança pequena

nós a voltamos e a obrigamos a olhar para trás

para o mundo das formas, não para o Aberto, 
que é tão profundo na face do animal. Livre da morte.

O animal vê o que está lá fora, o Aberto, o que não vemos com nossos olhos invertidos - olhos cegos pela consciência, treinados desde a infância a olhar para o mundo rubricado das formas, olhos que nos tornam incapazes de olhar o mundo. Algo paradoxal se insinua aqui: o desejo de poder olhar o mundo, este mundo, é o desejo de poder ver o que está fora. Em uma carta a um amigo russo, que cito aqui por intermédio de Maurice Blanchot (1987: 152), Rilke busca esclarecer o que entende pelo Aberto, ajudando-nos a habitar esse paradoxo, sem amortecê-lo: "entendemos por Aberto não o céu, o ar, o espaço que para o observador ainda são objetos e, por isso, opacos" -; a condição de ter, "para além de si, essa liberdade incrivelmente aberta" estaria antes no fato de que "o animal, a flor é tudo isso sem se dar conta de que é" (grifo nosso). A criatura vê o Aberto "com todos os olhos": não é a sede (consciente) da operação visiva. Ver o Aberto não se distingue de estar no Aberto, ser o Aberto, pois o Aberto não é um objeto ou uma destinação.

0 desejo de um fora se deixa compreender aqui, então, em sintonia com aquele atraente paradoxo, segundo o qual, como disse uma vez Wittgenstein (1996: 7), “o lugar para onde devo ir é um lugar onde já tenho que estar agora". Mas se é verdade que, assim considerados, fora e dentro não se relacionam por oposição, também é verdade que as cenas recém descritas de Adeus à Linguagem não deixam de nos dar, afinal, notícia do desejo de um fora: uma urgência de alteridade parece, de fato, atravessar e mover o filme como um todo. Muitas são as cenas de guerra, destruição, massacre; muitas são as falas sobre o fascismo, a opressão capitalista, o desgoverno da tecnologia; muitas são, enfim, as provocações retóricas sobre o nosso estado de horror (ouve-se, por exemplo, a pergunta: "estará a sociedade inclinada a aceitar o assassinato como forma de conter o desemprego?"). Em certo momento, um dos personagens, M. Davidson, um professor, diz, enquanto folheia um livro com imagens de Nicolas de Staël:

O que se passa? A continuação de um mundo exausto, custe o que custar? 0 fim desse mundo? 0 advento de um mundo diferente? Que é isso que nos acontece neste início de século, isso que parece não ter nome claro em nenhuma língua conhecida?

N. 41 - 12/ 2019| 171-190 - ISSN 2183-2242 | http:/dx.doi.org/10.21747/21832242/litcomp41a8 
As palavras citadas, aqui e no filme, abrem um livro de Alain Badiou sugestivamente intitulado Le Réveil de l'Histoire (2011). ${ }^{3}$ Trago-as aqui porque dão uma expressão, digamos, "didática" para o desejo de alteridade de que acabo de falar - e isso não porque enunciem um diagnóstico preciso, supostamente capaz de municiar consciências estrategistas, sabedoras de caminhos e necessidades específicas de mudança. Muito ao contrário, em sua articulação interrogativa, as palavras de Badiou reúnem - em suspensão - a exaustão, a continuação obstinada, o fim desde sempre decretado, a iminência do novo e da diferença. Comunicam, assim, mais uma atmosfera desejante do que propriamente desejos particulares. E dão ao mesmo tempo o sinal oblíquo de uma vontade de linguagem (diria que, com Godard, não tanto de nomes) - uma vontade que é também inseparável de um adeus à linguagem. Assim se deixam ler as palavras do filósofo, pelo menos dentro do filme que as canibaliza.

Em uma entrevista de 2014, Godard responde a uma pergunta sobre o título que deu ao filme, comentando que, no dialeto falado na parte da Suíça onde mora, o cantão de Vaud, "adeus" também quer dizer "olá". Mais interessante, talvez, do que essa "explicação" sujeita a evocar um (redutor) jogo entre otimismo e pessimismo, em tudo alheio ao acontecimento que é este filme - é o que Godard diz, na mesma entrevista, sobre a opção de filmar em 3D: "quando uma técnica está começando, é como uma criança, não tem regras; não demora muito para que se comece a ensinar a criança a falar, ir à escola, pagar impostos e tudo o mais". Para ele, o mundo do 3D estaria ainda relativamente invulnerável a esses gestos reguladores, e favorável, portanto, à experimentação e à invenção.

Nesse filme, que pensa a linguagem criando-a, é de se notar que a experiência do espectador se conclua ao som de gritos e balbucios de uma criança (sobrepostos a latidos): o filme termina assim, com a convocação literal e explícita de uma linguagem em estado nascente, intensiva, afetiva, musical, sem palavras. "Fazer a língua balbuciar", diz-nos Deleuze (1994: s.p.), é uma das forças especiais da literatura e da arte de um modo geral, sendo, para ele, importante ressalvar e enfatizar: "não estou falando de você balbuciar, mas 
de fazer a língua balbuciar". Como Godard faz balbuciar a língua neste filme que termina com alguém, uma criança, de fato balbuciando?

Um dos muitos meios de reagir a essa pergunta é atentar para os modos singulares que Godard tem de se haver com o trabalho da citação, o jogo de improvável liberdade que promove entre citação e invenção. É de fato um dos traços celebrados nos seus filmes a força vertiginosa com que eles deslocam, e fazem agir, os fragmentos "saídos de mil focos de cultura" de que falava Barthes (2004: 62), em suas tão citadas palavras sobre o reino inexorável da citação. Estas linhas já nos trouxeram alguns exemplos, Valéry, Rilke, Badiou, amostra tímida da experiência torrencial em que o filme nos envolve.

Godard vai de fato com volúpia aos nossos repertórios culturais - ele nos traz, misturadas, palavras de filósofos, poetas, romancistas, jornalistas, historiadores, psicanalistas, sociólogos; imagens de pintores, de cineastas, de arquivos públicos. Ocorre de os autores serem nomeados, como no caso de Rilke, mas, na maioria das vezes, palavras e imagens alheias são apropriadas, e não raro um pouco modificadas, sem referências (exceto nos créditos finais, sem muitos detalhes). Multiplicam-se, dentro do filme, leitores e espectadores, criando, além disso, camadas de citações. Que tipo de invenção é essa que se alia a um excesso tão desenfreadamente conspícuo de citações? Como esse furor citacional faz balbuciar a língua?

Para pensar como Godard pensa e realiza a invenção na linguagem, ajuda considerar mais esta breve sequência do filme. Roxy está deitado num sofá de uma sala iluminada. Ouve-se ao fundo o barulho de uma TV, diálogos em inglês. Corta-se para uma cena exterior, noturna, em que, sem que se deixe de ouvir o som da TV, um casal anda por uma rua escura. Saltamos então para um quarto pouco iluminado e agora podemos ver os donos das vozes que antes apenas entreouvíamos: na tela de uma TV enorme, Gregory Peck e Ava Gardner conversam, face a face, numa cena de As Neves do Kilimanjaro. De costas para a TV, em primeiro plano, uma das personagens do filme, Josette, abotoa a saia na cintura, afivela um cinto, depois se senta numa poltrona, sempre ignorando a televisão. Fora do quadro, uma voz masculina, a de Godard, se distribui pelo arco desse segmento, dizendo de forma 
ponderada, com pausas e repetições, a seguinte frase condicional: se o face a face inventa a linguagem. É interrompido por Josette:

G: Si le face à face (pausa) Si le face à face (pausa) Si le face à face invente le langage (pausa) Si

J: ré, $m i, f a, s o l, l a, s i$

G: la (pausa) la (pausa, mais baixo) la ${ }^{4}$

A hipótese hesitante não se deixa afinal completar; é interrompida por um sobressalto dialógico que, com um humor feminino, põe face a face a linguagem e a música, a lógica das hipóteses e a escala musical. Algo parece inventar-se nesse encontro que perturba discretamente a linguagem articulada: a segunda fala de Godard é, ao mesmo tempo, a continuação gaguejante da escala musical enunciada por Josette, o la-la-lá metonímico do canto e uma sequência pausada de três palavras, audíveis (e sugestivos) advérbios. Junto com tudo isso, o tempo todo, claro: imagens. Nesse segmento, ficam face a face Roxy e o espectador, Gregory Peck e Ava Gardner, a mulher e o homem, as palavras, as notas musicais. 0 face a face inventa a linguagem, podemos afirmar: o que antes era uma oração subordinada incompleta é agora um dito avulso, talvez uma máxima - um dito que, seja como for, se escapou à sua condição de simples hipótese, não terá sido pelas vias da lógica, mas por um gesto de adeus à linguagem.

"Quando digo adeus à linguagem, quero dizer sobretudo adeus ao meu modo de falar", diz Godard (2014: s. p.). Se a perturbação das palavras pelo encontro com as imagens e com a música é uma das formas de dar adeus aos nossos modos de falar, são, ao mesmo tempo, os nossos modos acostumados de ver que convidam perturbação, por vias recíprocas: "o que hoje chamamos de imagens tornou-se o assassinato do presente", diz M. Davidson em certo momento do filme. Nos planos visual e verbal, "estamos fora do prumo"; apegados a imagens assassinas do presente e reféns de uma compulsão de nomear - mas o cinema permite a renovação, ao "criar dentro de nós, em nosso interior, uma mistura de palavras e imagens" (Godard 2014: s. p.).

Para avançarmos um pouco mais, então, nos modos como Godard astucia suas misturas anárquicas, fiquemos agora com Roxy bebendo água num riacho, em silêncio total. 
Seguindo-se ao corte dessa cena, a próxima imagem nos chegará acompanhada de uma voz feminina, que diz, "nenhuma sede mais, a língua entra, a boca se fecha", enquanto o centro da tela se terá preenchido com a imagem em close de uma mão que, com os dedos esticados para frente, avança aos poucos sobre os espectadores, num efeito típico de 3D. Vemos ao fundo, desfocado, o rosto em cuja direção a mão então recuará lentamente, até que um novo corte traga uma cartela preta, com a interjeição "OH” em letras vermelhas - a voz feminina então continua: "deve ser uma linha reta". 0 último corte traz outra cartela preta, com a palavra "LANGAGE": é quando ouvimos "agora acabou, terminou, tive a imagem".

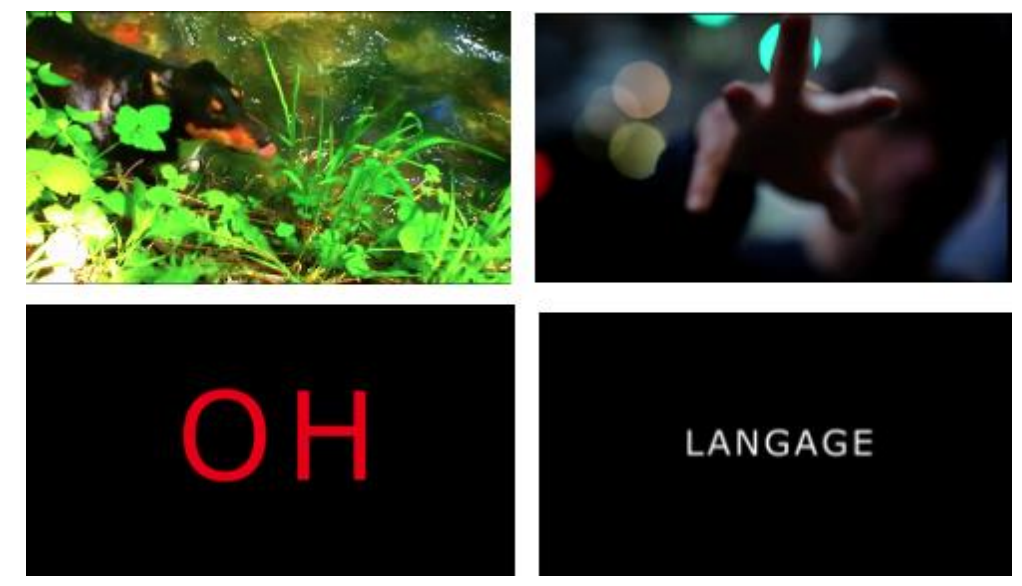

Fig. 3, Sequência de Adeus à Linguagem

Assim se misturam as imagens com as palavras que Godard traz aqui de L'Image, de Samuel Beckett (2003: 38): "nenhuma sede mais a língua entra a boca fecha deve ser uma linha reta agora acabou terminou tive a imagem" ${ }^{5}$. São palavras que afrontam a vida acostumada dessa palavra, "imagem", desorganizando sua oscilação pacífica entre os mundos visual e verbal (dizemos tanto de um escrito quanto de um quadro, por exemplo: que bela imagem). Beckett desfaz a calma da palavra também por arrancá-la de qualquer conforto que poderia ter no universo da metáfora ou da alegoria (como quando dizemos, por exemplo: eis como interpretar esta ou aquela imagem bíblica). A crua passagem de L'Image de que Godard se apropria faz ecoar de muitas maneiras o conhecido e sempre provocativo lema beckettiano: no symbols where none intended. ${ }^{6}$ 
Aqui é oportuno observar que Godard divide seu filme em partes, com a entrada de cartelas que, obedecendo com variações ao design daquelas vistas na figura 3, evocam os filmes mudos e também os livros, sua estrutura de capítulos. Recorrem as cartelas " 1 . Natureza” e "2. Metáfora”. O tema da metáfora marca seu protagonismo no filme em muitas outras ocasiões. A certa altura, ouvimos, por exemplo, a pergunta direta: "qual a diferença entre uma metáfora e uma ideia?”. E uma afirmação sobre a metáfora ("da espécie humana passamos à metáfora") tem lugar de destaque na própria sinopse do filme que, à época do lançamento de Adeus à Linguagem, Godard publicou no Twitter em forma de versos:

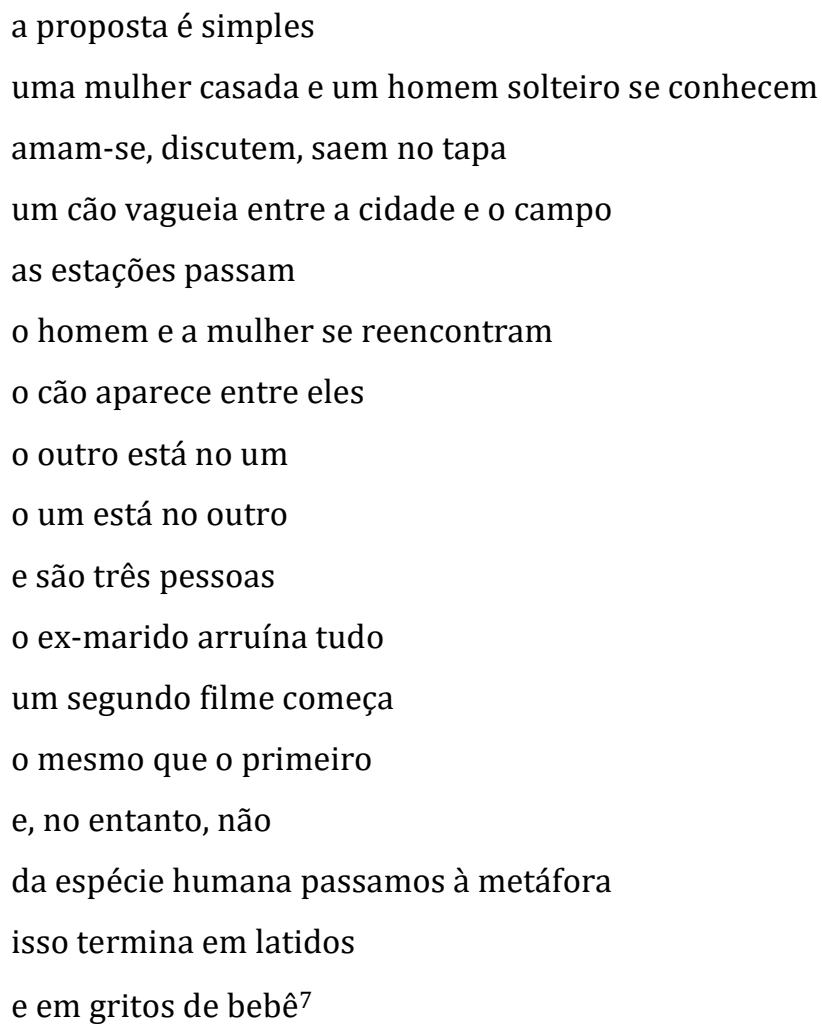

Da espécie humana passamos à metáfora - do capítulo natureza, passamos ao capítulo metáfora. Essas divisões são, no entanto, ao mesmo tempo convocadas e enfraquecidas: tudo termina em latido, grito, balbucio. Também Beckett escreve, em $O$ Inominável, que "é assim que tudo acabará, com gritos pungentes, murmúrios inarticulados 
(...) é assim que tudo acabará, com cacarejos, gluglu, ai, ah, pum, vou treinar-me, nham, hu, plof, psst, só emoção, ...” (Beckett 2002: 180).

No encontro de Beckett com Godard no filme, em poucos segundos, como se numa correnteza, passamos da língua de Roxy na água (natureza) a uma mão (espécie humana), que, como se fosse uma língua (metáfora), avança e recua em linha reta, ao som das palavras de Beckett, imagéticas provocações sobre a metáfora e a imagem. E tudo isso termina numa tocante interjeição: oh langage. Uma interjeição que é, ela mesma, achada nas dobras sonoras do título do filme. A interjeição inarticulada, afetiva - oh langage (como, em outro momento, ah dieux) - se deixa escutar no interior do Adieu au Langage de Godard.

Os encontros inventam a linguagem.

Com o protagonismo dado a Roxy, o filme explora, como vimos, o encontro entre o humano e o animal. A caminho de concluir esta breve reflexão, gostaria de trazer uma última sequência, para sublinhar outros encontros que Godard também frequenta.

A câmera passeia lenta pelo corpo deitado de uma mulher nua, entre o umbigo e a vagina; reconhecemos a citação ao quadro "A origem do mundo", de Courbet, enquanto escutamos uma mulher dizer: "os índios apaches chamam o mundo de floresta". Um corte nos leva a uma cena em preto e branco, passada em câmera bastante lenta: num bosque, um homem corre atrás de uma mulher (trata-se de um clipe do filme Menschen am Sonntag [Gente de domingo], Siodmak / Ulmer 1930). Junto às imagens desse clipe, alternam-se duas vozes. Primeiro, a mesma mulher diz: "esta manhã é um sonho, cada um deve pensar que o sonhador é o outro", palavras de Jorge Luis Borges. ${ }^{8}$ Em seguida, ouvimos Godard, citando Jacques Chardonne: "uma mulher é incapaz de fazer mal... ela pode te irritar, te matar, só isso". ${ }^{9}$ A voz feminina então retorna, para dizer, com Jean Anouilh: "[v]ous me dégoûtez tous avec votre bonheur. La vie qu'il faut aimer coûte que coûte. Je ne veux pas comprendre. Moi je suis là pour autre chose. Je suis là pour vous dire non et pour mourir. Pour vous dire non et pour mourir."10 


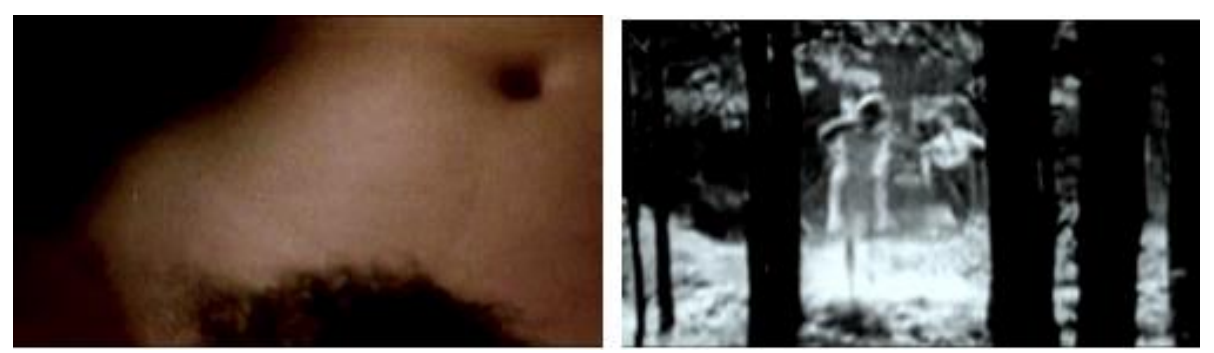

Fig. 4, Sequência de Adeus à Linguagem

"Os índios apaches chamam o mundo de floresta" - a cena começa pondo em jogo mais uma situação típica de alteridade, o encontro entre nós (seja lá o que for isso) e os índios, os que chamamos de índios. As nossas palavras e as deles. 0 mundo, ao ser chamado de floresta, ameaça deixar de ser mundo: como no quiasma de dois pontos de vista de que falava Valéry, não conseguimos pensar livremente, parece perturbar-se a paz do truísmo: a floresta é uma parte do mundo, não o mundo. Na circunstância sensível desse filme, a frase tão simples sobre os apaches nos expõe a algo mais do que curiosidades anedóticas de tipo Reader's Digest acerca das diferenças entre línguas e culturas. Expõe-nos talvez à imaginação de uma vida que desconhece as bordas de um mundo, tomado como objeto total, visto de cima. Uma vida passada numa horizontalidade de floresta, uma vida de participação num organismo sem fim, algo para o que parecem faltar palavras aptas, algo cuja promessa radical talvez pudéssemos descrever com a ajuda de Clarice Lispector, quando diz, em A Paixão Segundo GH: "a visão de uma carne infinita é a visão dos loucos" (Lispector 1998: 11).

E, por outro lado, também isto: chamam ainda o mundo de floresta, insistem no idioma de sua vida, os índios que já estão fartos de conhecer este nosso mundo de destruição, genocídio e etnocídio - o mundo a que foram e são submetidos (mesmo quando protegidos), destruídas literalmente as suas florestas. 0 mundo que demarcou e reservou para eles uma borda, uma margem, que lhes aponta o dedo e diz, como se fosse apenas uma questão de constatar o óbvio: margem do Ocidente. Outros momentos do filme dão sinal do interesse de Godard pelos encontros com essas (autoproclamadas) margens do dito Ocidente. A frase sobre os apaches se repete, assim como a pergunta: "é possível produzir 
um conceito de África?", a que poderíamos acrescentar: é o caso tentar produzir um conceito de África? Um conceito? A provocação mereceria muito mais reação aqui; cito-a, de passagem, porque me ajuda a sublinhar a possibilidade de que as dificuldades postas em jogo no face a face com as margens do Ocidente serão dificuldades mais produtivas e inventivas se não as tomarmos meramente como dificuldades conceituais.

O encontro entre nós e os índios apaches, nos poucos segundos em que estes comparecem mencionados no filme de Godard, contamina-se pelas palavras de Borges, que ouvimos na sequência, e que Godard cita subvertendo consideravelmente. Enquanto no filme se diz "esta manhã é um sonho, cada um deve pensar que o sonhador é o outro" [cette matinée est un rêve, chacun doit penser que le rêveur c'est l'autre], Borges diz, na tradução fiel de Davi Arrigucci Jr., "[s]e esta manhã e este encontro forem sonhos, cada um dos dois tem que pensar que o sonhador é ele" (Borges 1992: 9). Na versão de Godard, cada lado deve dizer: é você o sonhador; e, na de Borges, o sonhador sou eu. Mas, se nos dois casos, é um sonho a própria manhã do encontro, então, o que está em disputa, nas duas versões é, afinal, qual dos sonhos é aquele que vigora (sabendo-se sonho ou não).

No conto de Borges de onde esta passagem sai, "O outro", o encontro insólito se dá entre dois homens que são um mesmo homem em dois momentos de sua vida, juventude e velhice. Quando inserida de forma avulsa no filme de Godard, a frase vem perturbar, não os tempos de uma mesma vida no mundo, mas a própria fé na unicidade e na estabilidade do mundo. Se o que está em disputa no face a face com os apaches é qual dos sonhos vigora, não será este, então, um encontro ou um choque entre concepções, conceitos, modos diferentes de compreender. Será um encontro de sonhos no sonho de uma manhã - o sonho da vida num mundo total, internamente rubricado; e (talvez) o sonho da vida vivida como carne infinita, floresta sem bordas. 0 encontro, se houver, não se dará em um mundo que existe por si, indiferente ao sonho: porá isso sim em jogo a consistência mesma da vida - a própria matéria de que somos feitos, que, como ensina Shakespeare, é a matéria dos sonhos.

A experiência sensível do filme comove-nos para muito além dessas elucubrações, talvez excessivas. Voltamos ao filme e lembramos o que talvez os últimos parágrafos tenham esquecido, a saber, que floresta dos índios apaches nunca esteve separada da 
floresta de pelos na vagina da mulher deitada que vemos enquanto escutamos a frase de Borges. $\mathrm{O}$ face a face entre nós e os índios transborda no face a face entre homem e mulher - o pronome "nós" precisa ser perturbado, pois a nós mulheres também se reservaram e se reservam violência e margens objetivas, nisso estamos mais com os índios.

O desencontro e o encontro (amoroso, violento, amoroso-violento) entre homem e mulher responde, com efeito, pelo que há de estrutura (?) narrativa no filme, conforme indica a sinopse-poema de Godard, citada acima. A cena do diálogo com as notas musicais é apenas uma, entre muitas e muitas outras, que, no filme, trazem a mulher em inventiva desconformidade com o entorno masculino. Na sequência agora em consideração, que alterna, como vimos, a voz feminina e a masculina, um homem persegue uma mulher, em velocidade muito lenta: deixa-nos talvez suspensos entre o amor e a violência. Contribui para essa suspensão a frase humorada de Chardonne: a mulher, incapaz de fazer mal, pode apenas irritar, matar, "só isso". O homem persegue na tela a mulher, que, sem ser capaz de fazer mal, pode matar. Desorganiza-se a distribuição das forças e da violência, suspende-se a moral que rege de hábito a palavra "mal".

Ao citar Chardonne, Godard omite uma frase do original: o homem "carrega em si mesmo sua própria tragédia" (Chardonne 1952: 41). E é de dentro de uma tragédia escrita por homens (Sófocles, Anouilh) que a voz feminina virá irromper e redarguir, como se num diálogo, a fala de Godard/Chardonne - e responder também, talvez, ao coro de vozes tão majoritariamente masculinas com que Godard faz girar a sua máquina de citações. Antígona diz e é preciso repetir: não está aqui para amar a vida custe o que custar, não está aqui para entender - está aqui para dizer não.

Uma das epígrafes com que Godard abre seu filme anuncia: "resta saber se o nãopensamento contamina o pensamento". 0 não com que Antígona se recusa a amar a vida custe o que custar é talvez não-pensamento - ela não veio para entender. Mas, como naquele paradoxo de Wittgenstein, o lugar aonde devo chegar só pode ser o lugar onde já estou - o não-pensamento não seria um fora do pensamento tomado como um atributo (da mulher, do animal, do índio), não seria um objeto, não seria uma destinação. Seria mais uma possibilidade sempre latente de contaminação, a possibilidade de tornar sensíveis forças 
rarefeitas, em grande parte, pelo medo da desorganização profunda, que nos faz amar uma certa vida custe o que custar. Estendendo os versos da sinopse de Godard, poderíamos, nesse sentido, dizer: o homem, a mulher, o animal, o índio, a natureza, a metáfora, a imagem, a palavra - um está no outro, o outro está no um, e, no entanto, não.

O movimento que desenvolvi aqui orientou-se para pensar a relação entre literatura e cinema por atenção à vida que levam no filme (e ao filme) alguns dos fragmentos literários ali citados. Busquei mostrar que o face a face entre cinema e literatura que Godard promove é ocasião para invenção de linguagem e responde ao desejo de alteridade que atravessa o filme. Mas é de um modo bastante singular que a máquina de citações de Godard é posta a serviço da invenção. Uma forma de compreender essa singularidade nos devolve à silhueta escura de Roxy.

Reparemos, voltando à figura 1, que essa silhueta poderia se confundir com a sombra de um corpo que, estando conosco dentro da sala de cinema, se projetasse na tela por interpor-se diante da luz do projetor (como ocorre quando um espectador entra atrasado). Pensemos então em Roxy conosco na sala de cinema, vendo "com todos os olhos", não um trem que passa rápido, mas o próprio filme de Godard - vendo como vê tudo o mais, vendo um organismo vivo, participando desse organismo.

Em depoimento sobre seu La Région Centrale, Michael Snow observou uma vez, sobre a tela do cinema, que "um único retângulo pode conter muita coisa"; insistia ali que o quadro é muito importante, "na medida em que a imagem está continuamente fluindo através dele" - e conclui: "o quadro são as pálpebras" (Snow apud Towsend 2015: 202).

Roxy conosco no cinema e o filme: encontro de pálpebras. 0 filme nos olha um pouco como um cachorro nos olha, limitamo-nos reciprocamente. 0 mesmo se poderia dizer de um livro, de um verso, de um quadro, de uma sinfonia, de uma frase musical. Um verso olha uma imagem e é olhado por ela. Também desse encontro de pálpebras, com sorte, inventase linguagem, faz-se no possível o impossível. 
"Resta saber se o não-pensamento contamina o pensamento"

\section{NOTAS}

${ }_{1}$ Personne ne pourrait penser librement si ses yeux ne pouvaient quitter d'autres yeux qui les suivraient. Dès que les regards se prennent, l'on n'est plus tout à fait deux, et il y a de la difficulté à demeurer seul. (Valéry 1960: 490-491). A tradução é nossa, aqui e sempre que não houver outra indicação. Para as traduções de língua francesa, contamos com a ajuda valiosa de Maria Helena Franco Martins.

${ }^{2}$ Ce qui est au-dehors, écrivait Rilke, nous ne le savons que par le regard de l'animal. No original de Rilke: ... Was draußen ist, wir wissens aus des Tiers / Antlitz allein ... (Rilke 1989: 64)

${ }^{3}$ Que se passe-t-il? (...) Continuation vaille que vaille d'un monde fatigué? (...) Fin de ce monde? Avènement d'un autre monde? Que nous arrive-t-il donc, à l'orée du siècle, qui ne semble avoir aucun nom clair dans aucune langue tolérée? (Badiou 2011: 7)

${ }^{4}$ Cito a passagem em francês, contrariando a prática adotada até aqui, para aproveitar a homografia, ausente em português, entre a conjunção "si" [se] e a nota musical "si" [si] (a homofonia, é claro, se verifica nas duas línguas). As rubricas entre parênteses são minhas.

${ }^{5}$ Esta passagem, que aparece primeiro em 1959, em L'Image (Beckett, 1988), foi reproduzida em obra posterior de Beckett, Como é (Beckett 2003), que cito aqui, na tradução de Ana Helena Souza.

${ }^{6}$ Em tradução aproximada: "nada de símbolos quando disso não houve a menor intenção". Em francês, Beckett reescreveu assim o seu imperativo anti-simbólico: honni soit qui symboles y voit [envergonhemse aqueles que aí veem símbolos], variação do célebre honni soit qui mal y pense.

7 le propos est simple/ une femme mariée et un homme libre se rencontrent/ ils s'aiment, se disputent, les coups pleuvent / un chien erre entre ville et campagne / les saisons passent / L'homme et la femme se retrouvent/ le chien se trouve entre eux / l'autre est dans l'un / l'un est dans l'autre/ et ce sont les trois personnes / l'ancien mari fait tout exploser / un deuxième film commence / le même que le premier / et pourtant pas / de l'espèce humaine on passe à la métaphore / ça finira par des aboiements / et des cris de bébé (Godard 2014b: s.p.)

${ }^{8}$ Godard modifica um pouco o original, que cito aqui em tradução de Davi Arrigucci Jr.: "Se esta manhã e esse encontro forem sonhos, cada um dos dois tem que pensar que o sonhador é ele." (Borges 1992: 9)

9 Godard modifica e corta um pouco o original, que vale restituir na íntegra: Une femme ne peut pas beaucoup nuire à un grand homme. Il porte en lui-même toute sa tragédie. Elle peut le gêner, l'agacer. Elle peut le tuer. C'est tout. (Chardonne 1952: 41)

10 Cito-as em francês para preservar a ambiguidade do pronome "vous" (vocês, o senhor), que, em português, teria que ser decidida (Anouilh 1952: 82 e 93). Trago aqui a tradução de Sidney Barbosa, que mostra que Godard omite passagens e repete a última frase por conta própria: "O senhor me enoja com essa sua felicidade que é preciso amar custe o que custar. [...] Eu não quero entender. [...] Eu estou aqui para outra coisa e não para entender. Eu estou aqui para dizer não e para morrer." (Anouilh 2009: 83 e 92)

N. 41 - 12/ 2019 | 171-190 - ISSN 2183-2242 | http:/dx.doi.org/10.21747/21832242/litcomp41a8 


\section{Bibliografia}

Anouilh, Jean (1952), Antigone, Paris: Didier.

-- (2009), Antígona, tradução de Sidney Barbosa, Brasília, Editora da UNB.

Badiou, Alain (2011), Le Réveil de l'Histoire, Paris, Éditions Lignes.

Barthes, Roland (2004), A morte do autor, in O Rumor da Língua, tradução de Maria Laranjeira, São Paulo, Martins Fontes, p. 57-64.

Beckett, Samuel (2002), O inominável, tradução de Maria Jorge Vilar de Figueiredo, Lisboa, Assírio e Alvim.

Beckett, Samuel (2003), Como é, tradução de Ana Helena Souza, São Paulo, Iluminuras.

-- (2006) Watt, in Samuel Beckett: The Grove centenary edition. Paul Auster (org), vol. I, New York: Grove Press.

Blanchot, Maurice (1987), O espaço literário, tradução de Álvaro Cabral, Rio de Janeiro, Rocco.

Borges, Jorge Luis (1992), “O outro”, in O livro de areia, tradução de Davi Arrigucci Jr., São Paulo: Companhia das Letras.

Chardonne, Jacques (1952), Eva ou le journal interrompu. Claire, OEuvres complètes III, Paris, Albin Michel.

Deleuze, Gilles / Parnet, Claire (1994), L'Abecedaire, transcrição e vídeo completo <http://clinicand.com/2018/06/13/o-abecedario-de-gilles-deleuze/> (último acesso em 15/09/19).

Godard, Jean-Luc (2014), “Exclusive Interview with the Legend (Part 1)", <https://www.youtube.com/watch?v=Bou1w4LaqMo > (último acesso em 20/10/19).

-- (2014b), “Le résumé d"Adieu au Langage' rédigé par JLG", <https://twitter.com/victorsaintmac/status/457081659402100736> (último acesso em 
$17 / 10 / 2019)$.

Lispector, Clarice (1998), A paixão segundo G. H., Rio de Janeiro, Rocco.

Rilke, Rainer Maria (1968), As Elegias de Duíno e Sonetos a Orfeu, tradução de Paulo Quintela, Porto, Editorial Inova.

-- (1989), Duineser Elegien / Duino Elegies, Translated by Stephen Cohn, Evanston Illinois, Northwetern University Press.

Snow, Michael / Townsend, Charlotte (1971), “Convergindo para La Région Centrale: uma conversa entre Michael Snow e Charlotte Townsend", in: DUARTE, Theo; MOURÃO, Patrícia (Orgs.). Cinema Estrutural. Rio de Janeiro: Caixa Cultural Rio de Janeiro, 2015. p. 196-202.

Valéry, Paul (1960), CEuvres II, Paris, Gallimard, Collection: Bibliothèque de la Pléiade. Wittgenstein, Ludwig (1996), Cultura e valor, tradução de Jorge Marques, Lisboa, Edições 70.

\section{Filmes citados:}

Godard, Jean-Luc, Adieu au Langage, Suíça e França, 2014.

King, Henry, The Snows of Kilimanjaro, Estados Unidos, 1952.

Siodmak, Robert / Ulmer, Edgar G. Menschen am Sonntag, Alemanha, 1930. 
Helena Martins é Professora Associada do Departamento de Letras da Pontifícia Universidade Católica do Rio de Janeiro e pesquisadora bolsista de produtividade do CNPq. Sua pesquisa frequenta a interface entre a filosofia e os estudos da linguagem e da literatura, com interesse especial pelos pensamentos de orientação perspectivista, tomados como ocasiões favoráveis para repensar temas clássicos como a tradução; a metáfora; a tensão entre dizer e fazer; o devir das línguas/formas de vida; as potências da literatura e da arte; os limites da linguagem. 